\title{
EXTRACTS OF ELECTRIC LOBE AND ELECTRIC ORGAN FROM TORPEDO CALIFORNICA INCREASE THE TOTAL NUMBER AS WELL AS THE NUMBER OF AGGREGATES OF CHICK MYOTUBE ACETYLCHOLINE RECEPTORS ${ }^{1}$
}

\author{
JOE A. CONNOLLY, ${ }^{2}$ PAUL A. ST. JOHN, ${ }^{3}$ AND GERALD D. FISCHBACH ${ }^{4}$ \\ Department of Pharmacology, Harvard Medical School, Boston, Massachusetts 02115
}

Received September 18, 1981; Revised March 30, 1982; Accepted April 13, 1982

\begin{abstract}
Saline extracts prepared from the electric lobe, the electromotor nerves, and the electric organ (the electromotor system) of Torpedo californica increase the number of ACh receptors on uninnervated chick myotubes in culture, while extracts from $T$. californica liver or skeletal muscle do not. The extracts also increase the ACh sensitivity of treated myotubes, indicating that newly synthesized receptors are functional. The active substance(s) is heat sensitive but not trypsin sensitive. Gel filtration on Bio-Gel P-150 shows that the activity is associated with a peak of low $(<5,000$-dalton) molecular weight activity. Labeling studies with rhodamine-conjugated $\alpha$-bungarotoxin show that, in addition to their effect on receptor number, these extracts also cause aggregation of prelabeled ACh receptors on the myotube surface.
\end{abstract}

Cell-free saline extracts from embryonic chick brain or spinal cord (Jessell et al., 1979) or from rat central nervous system (Podleski et al., 1978) can increase the number of ACh receptors on cultured muscle cells. Apparently this change in receptor number is due to an increase in synthesis, not decreased degradation of receptors (Jessell et al., 1979). In addition to increasing the number of receptors, these extracts also increase the number of receptor aggregates on treated myotubes. Christian et al. (1978) reported that conditioned medium from neuronal cells increases the number of $\mathrm{ACh}$ receptor aggregates without increasing the total number of recep-

\footnotetext{
${ }^{1}$ We wish to thank Jonathen Cohen and Keith Miller for providing us with much of the Torpedo tissue used in these experiments, Julia Matthews-Bellinger for the rhodamine-labeled toxin, and Yehezkel Gottlieb for help with some of the electrophysiological experiments. This work was supported by grants from the National Institutes of Health (NS 11160) and Muscular Dystrophy Association to G. D. F. J. A. C. is the recipient of a Fellowship from the Medical Research Council of Canada and P. A. St. J. is a National Institutes of Health Postdoctoral Fellow (TG NS 07009).

${ }^{2}$ To whom correspondence should be addressed at his present address: Department of Anatomy, University of Toronto, Toronto, Ontario, Canada M5S 1A8.

${ }^{3}$ Present address: Laboratory of Neurophysiology, National Institutes of Health-National Institute of Neurological Diseases and Stroke, Bethesda, MD 20205.

${ }^{4}$ Present address: Department of Anatomy and Neurobiology, Washington University School of Medicine, 660 South Euclid Avenue, St. Louis, MO 63110.
}

tors. It has been suggested that extracts can induce receptor clusters, at least in part, by causing the aggregation of receptors already exposed on the surface of the myotube (Prives et al., 1980).

ACh receptor-inducing activity may be unique to cholingeric neurons. Previous work from this laboratory has shown that medium conditioned by ciliary ganglion cells, a pure population of cholinergic neurons, increased the number of myotube $\mathrm{ACh}$ receptors, while medium conditioned by presumably non-cholinergic dorsal root ganglion cells had no effect (Jessell et al., 1979; Fischbach and Jessell, 1980). Cohen and Weldon (1980) have demonstrated that Xenopus spinal cord cells, many of which are cholinergic (Anderson et al., 1977, 1979), induce clusters of ACh receptors along the path of nerve-muscle cell contact in vitro, whereas dorsal root ganglion or sympathetic ganglion cells do not.

The electromotor system of Torpedo is an excellent system for the study of cholinergic synapses (see Whittaker, 1977, for a recent review). Neuroelectrocyte synapses are cholinergic (Feldberg and Fessard, 1942) and kilogram amounts of organ can be obtained from a single fish. Each organ is innervated by nerves which arise directly from the electric lobe, a bilateral eminence on the brain stem posterior to the cerebellum. The lobe contains only electromotor neurons which provide cholinergic innervation to the electric organ (Able-Fessard and Buser, 1954; Bennett, 1970; Tsuji, 1977). In this study, we report that saline extracts from the Torpedo 
californica electromotor system can increase the number of ACh receptors as well as the number of receptor clusters on chick myotubes.

\section{Materials and Methods \\ Cell-free extracts}

Torpedo californica tissue was either dissected from live fish or material previously frozen in liquid nitrogen was purchased from Pacific Bio-Marine (Venice, CA). Up to $1 \mathrm{~kg}$ of electric organ (EO) could be obtained from a single fish; the paired electric lobes (ELs) from one fish usually weighed 0.75 to $1.0 \mathrm{gm}$. Fresh material could be stored at $-80^{\circ} \mathrm{C}$ for several weeks with no appreciable loss of biological activity.

To prepare $T$. californica extracts, the tissue was homogenized in Puck's saline (Puck et al., 1958) in a Dounce homogenizer at a ratio of $1 \mathrm{gm}$ of tissue $/ 3 \mathrm{ml}$ of saline. The crude extract was filtered through gauze and centrifuged at $10,000 \times g$ for 20 min to produce a low speed supernatant (LSS) and a low speed pellet (LSP), and the latter was resuspended in the same volume as the LSS. The LSS then was centrifuged at $200,000 \times g$ for $2 \mathrm{hr}$ to produce high speed supernatant (HSS) and pellet (HSP) fractions, and the HSP was resuspended in the same volume as the HSS. The equipment and solutions used were sterile, but no subsequent attempts were made to sterilize the final extracts.

When the LSP extracts from the electric organ were added to cultures of myotubes, very large increases (up to 40 -fold) were seen in the binding of ${ }^{125} \mathrm{I}-\boldsymbol{\alpha}$-bungarotoxin (described below). However, the material in this fraction would bind large amounts of toxin, and if cold (unlabeled) $\alpha$-bungarotoxin was added to the fraction before addition to the cells, no increase in toxin binding was seen. Since this fraction obviously contains large numbers of $\mathrm{ACh}$ receptors (AChRs), we chose to concentrate in subsequent experiments on the LSS fraction separated by centrifugation into HSP and HSS fractions.

Extracts of embryonic chick brain (15 to 19 days in ovo) were prepared by the same method.

\section{Cell culture}

Embryonic chick muscle cultures were prepared from dissociated myoblasts as previously described (Fischbach, 1972), except no trypsin was used in the dissociation. Cells were plated at a density of $10^{5} / \mathrm{ml}$ on collagencoated Costar 96 -well cluster plates $(0.1 \mathrm{ml} /$ well $)$ or on collagen-coated glass coverslips in $35-\mathrm{mm}$ Falcon dishes $(1.0 \mathrm{ml} /$ dish). Cells were plated (day 0) in Eagle's minimal essential medium with Earle's balanced salt solution (BSS) supplemented with $10 \%$ horse serum and $5 \%$ chick embryo extract (CEE). On day 3, the cells were fed with the same medium containing only $2 \% \mathrm{CEE}$.

For the treatment of myotubes with tissue extracts, cells were fed daily with medium containing $1 \%$ CEE starting on day 4 . Myotubes were treated routinely with extract for 4 days, from days 4 to 7 of culture, and 1 to 10 $\mu 1 /$ well/day was added. In some experiments, extracts were added for only 1 day. In this case, the medium was changed daily, but extracts were added only on day 7 .

\section{ACh receptor assays}

${ }^{125} I$ - $\alpha$-bungarotoxin binding. To measure the specific binding of ${ }^{125} \mathrm{I}-\alpha$-bungarotoxin (BGT), cells were grown in 96 -well cluster plates. On day 8 , the medium was removed, the cells were washed once in BSS, and $50 \mu \mathrm{l}$ of BSS containing $5 \times 10^{-} 9 \mathrm{M}{ }^{125} \mathrm{I}-\alpha$-BGT (New England Nuclear, Boston, MA; specific activity, $17.5 \mu \mathrm{Ci} / \mathrm{mg}$ ) was added. Cells were incubated for $60 \mathrm{~min}$ at $37^{\circ} \mathrm{C}$ and washed by repeated immersion in 2 liters of BSS, the contents of each well was dissolved in $200 \mu \mathrm{l}$ of $1 \mathrm{~N} \mathrm{NaOH}$ containing $500 \mu \mathrm{g} / \mathrm{ml}$ of sodium deoxycholate, and radioactivity was measured in a Beckman Gamma 300 counter. At least eight replicate wells were used for each condition. To measure nonspecific binding, eight wells were incubated with the same radioactive toxin mixture containing a large excess of unlabeled $\alpha$-BGT $\left(5 \times 10^{-7} \mathrm{M}\right)$ and $d$ tubocurare $\left(2 \times 10^{-4} \mathrm{M}\right)$ and the mean value for this set of wells was subtracted from the total counts for each test well to give a value for specific toxin binding. These values were averaged to give a mean binding value for each test condition.

ACh iontophoresis. For these studies, cells were grown on glass coverslips. The ACh sensitivity of control and treated cultures was assayed by measuring the deplorization caused by applying ACh iontophoretically from an electrode filled with 1 м ACh. The positive iontophoretic current pulse was $1.0 \mathrm{msec}$ in duration and $10 \mathrm{nA}$ in amplitude; the negative "bucking" current was about 2 nA. The index of ACh sensitivity used here, millivolts of depolarization per nanocoulomb of charge ejected $(\mathrm{mV} / \mathrm{nC})$, was calculated after measuring the current pulse and the membrane potential change directly on a storage oscilloscope screen.

Rhodamine $\alpha-B G T$ labeling. To examine the distribution of receptor clusters in control and extract-treated cells, myotubes grown on glass coverslips were incubated in complete medium containing $0.1 \mu \mathrm{M}$ tetramethylrhodamine-labeled $\alpha$-BGT (R-BGT; prepared by Julia Matthews-Bellinger according to the method of Ravdin and Axelrod (1977)) for $60 \mathrm{~min}$ and then washed three times (30 min each) in fresh medium. Cells were rinsed in BSS,

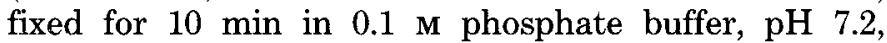
containing $2 \%$ formaldehyde (freshly prepared from paraformaldehyde) and $0.1 \mathrm{M}$ sucrose, washed three times in phosphate buffer alone, and mounted in phosphatebuffered saline/glycerol (50/50), $\mathrm{pH} 7.8$.

The density of the clusters was estimated by examining 10 different fields of myotubes under $\times 40$ magnification for each sample; clusters were counted under an ocular grid in each field using fluorescent illumination (Leitz epi-illuminator with a $100-\mathrm{W}$ mercury light source; Leitz N2 filter cube) and the muscle cell surface area was determined by counting the intersection points in the ocular grid (13.5- $\mu \mathrm{m}$ squares).

To examine the fate of receptors already exposed on the cell surface at the time of extract addition, myotubes were labeled with R-BGT for $60 \mathrm{~min}$, washed, and then placed in medium containing extract. In these experiments, these "prelabeled" receptors were exposed to extracts for relatively short periods of time, 8 or $24 \mathrm{hr}$.

\section{Results}

Extracts prepared from tissues of Torpedo californica were assayed for their effect on myotube $\mathrm{ACh}$ receptor number by measuring the binding of ${ }^{125} \mathrm{I}-\alpha$-BGT to treated cells. The HSPs and HSSs from the T. califor- 
nica electromotor system caused a significant $(p<0.005)$ increase in the binding of ${ }^{125} \mathrm{I}-\alpha$-BGT to chick myotubes (Fig. 1). Myotubes treated with the same fractions prepared from $T$. californica skeletal muscle did not produce an increase and fractions prepared from the liver produced a decrease (Fig. 1). It should be noted that these liver fractions were toxic to the cells, and within 1 to 2 days of extract addition, the majority of cells had pulled off of the substrate.

Electric organ. The addition of EO-HSP resulted in a 7 - to 10 -fold increase in the binding of ${ }^{125} \mathrm{I}-\alpha$-BGT to treated myotubes (Fig. 1; Table I); however, this does not reflect any increase in myotube $\mathrm{ACh}$ receptor number but simply the fact that a large number of Torpedo ACh receptors are present in the EO-HSP. Pretreatment of this fraction with unlabeled $\alpha$-BGT eliminated the increase. In addition, the extract itself would bind toxin sufficient to account for any increase seen (Table I). Moreover, there was no significant increase in the $\mathrm{ACh}$ sensitivity of EO-HSP-treated fibers (Table I). Considering published protocols for the preparation of ACh receptor-rich Torpedo membrane (e.g., Sobel et al., 1977), it is not surprising that low speed centrifugation failed to remove all of the toxin binding sites.

On the other hand, EO-HSS produced a dose-dependent increase in ${ }^{125} \mathrm{I}-\alpha$-BGT binding (increases in binding of 1.0- to 1.7-fold over control were seen over a concentration range of 1.6 to $16 \mu \mathrm{g}$ of electric organ protein added per day) that probably does reflect an increase in the number of myotube ACh receptors (Fig. 1; Table I). First, experiments with ACh receptor-rich Torpedo membrane fragments (P. A. St. John, unpublished observations) indicate that fewer than $0.002 \mathrm{fmol}$ of ${ }^{125} \mathrm{I}-\alpha$ -

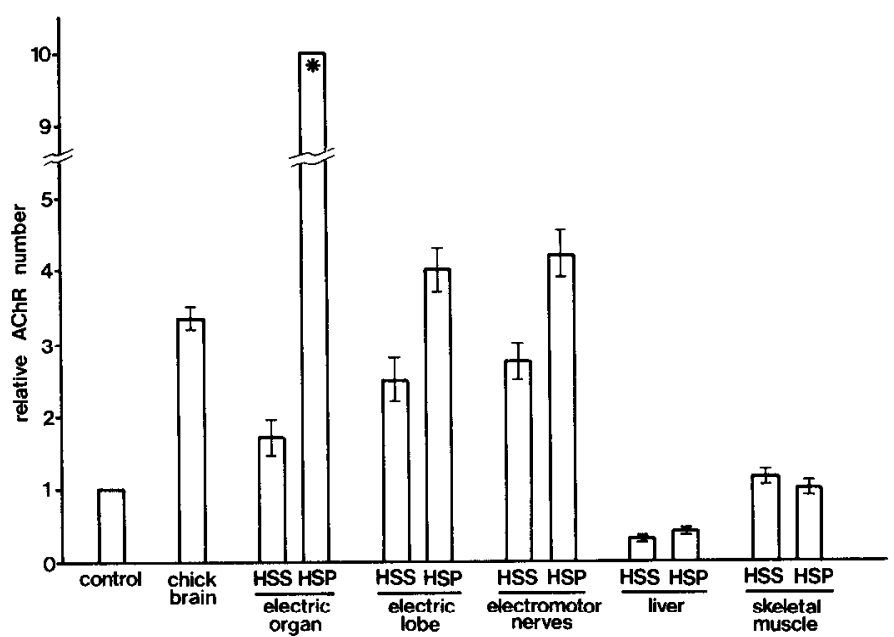

Figure 1. Effects of $T$. californica extracts on the binding of ${ }^{125} \mathrm{I}-\alpha$-BGT to chick skeletal muscle cells in culture. Cells grown in 6-mm wells (microwells) were fed on each of 4 successive days, beginning on day 4 of culture, $100 \mu \mathrm{l}$ of $1 \%$ medium. In addition, each well received $10 \mu \mathrm{l} /$ day of the extract indicated; control wells received $10 \mu \mathrm{l}$ of saline. After 4 days, ${ }^{125} \mathrm{I}-\alpha$-BGT binding was determined. In each experiment, the amount of ${ }^{125} I$ bound in extract-treated wells was expressed relative to the amount bound in control wells (eight wells per condition). The bars represent the average of three experiments; the error bars indicate the standard error of these means. HSS, High speed supernatant; HSP, high speed pellet. * The large increase in toxin binding seen in EO-HSP-treated wells is due to exogenously added $\mathrm{ACh}$ receptors; see text.

\section{TABLE I}

Properties of $T$. californica electric organ extracts

Table I represents the values obtained from a single series of experiments using the same electric organ extracts. The protein concentrations used were: EO-HSP, $0.31 \mathrm{mg} / \mathrm{ml}$ and EO-HSS, $1.63 \mathrm{mg} / \mathrm{ml}$. For ${ }^{125} \mathrm{I}-\alpha$-BGT binding to myotubes, ${ }^{125} \mathrm{I}-\alpha$-BGT binding was determined on day 8 of culture. The numbers are the means \pm SD for specific femtomoles of toxin bound per test condition. The numbers in parentheses are the ratios of values for a given test condition to the control value. In experiment 1 , myotubes in microwell cultures were treated with extract for 4 days, from days 4 to 7 of culture. In experiment 2 , myotubes in microwell cultures were treated with extract for 1 day, added on day 7 of culture. For $\alpha$-BGT-blocked extract, extracts were incubated with excess unlabeled $\alpha$-BGT for $60 \mathrm{~min}$, washed three times by centrifugation, and then added to the cells. For ${ }^{125} \mathrm{I}-\alpha$-BGT binding to extracts, fractions were incubated with excess ${ }^{125} \mathrm{I}-\alpha$-BGT for $60 \mathrm{~min}$, washed three times by centrifugation, and then total counts were determined in the final pellet. Control samples were treated in the same fashion except the iodinated toxin mixture contained a 100 -fold excess of unlabeled $\alpha$-BGT. The numbers are the difference between control and test conditions expressed as the number of femtomoles of toxin bound per $10 \mu \mathrm{l}$ of extract. ACh sensitivity was determined on untreated or extract-treated fibers as described under "Materials and Methods." The numbers are the geometric means of the ACh sensitivity of all fibers tested; the numbers in parentheses are the ratios between treated and control fibers.

\begin{tabular}{lccc}
\hline & Control & HSP & HSS \\
\hline $\begin{array}{c}{ }^{125} \mathrm{I}-\alpha \text {-BGT binding to } \\
\text { myotubes }\end{array}$ & & & \\
Experiment 1 & $4.0 \pm 0.8$ & $27.5 \pm 3.4$ & $7.0 \pm 1.4$ \\
& & $(6.9 \times)$ & $(1.7 \times)$ \\
Experiment 2 & $5.5 \pm 1.1$ & $18.8 \pm 1.7$ & \\
$\quad$ Untreated & $5.5 \pm 1.1$ & $(3.4 \times)$ & \\
& & $(1.0 \times 1.6$ & \\
$\alpha$-BGT blocked & & 14.7 & \\
& & & \\
& & & \\
${ }^{125} \mathrm{I}-\alpha$-BGT binding to & & & \\
extracts & & 204 & \\
& & $(1.2 \times)$ & $(2.9 \times)$ \\
\hline ACh sensitivity & & & \\
& & & \\
\end{tabular}

BGT binding sites $/ 10 \mu \mathrm{l}$ would remain in the EO-HSS following centrifugation at $200,000 \times g$ for $2 \mathrm{hr}$; therefore, the amount of toxin binding sites added accounts for less than $1 \%$ of the increase in binding seen on EO-HSStreated myotubes. Second, electrophysiological experiments showed that EO-HSS-treated fibers were more sensitive to ACh. The ACh sensitivity of small patches of untreated myotube membrane, assayed with brief pulses of ACh, ranged widely between 40 and $500 \mathrm{mV} /$ $\mathrm{nC}$ with a geometric mean of $173 \mathrm{mV} / \mathrm{nC}$ (57 sites on 12 myotubes). The sensitivity of extract-treated cells also ranged widely between 260 and $1100 \mathrm{mV} / \mathrm{nC}$, but the geometric mean of $509 \mathrm{mV} / \mathrm{nC}$ ( 28 sites on 6 myotubes) was significantly greater than the control $(p<0.005)$. Thus, the EO-HSS contains a factor(s) that causes an increase in the total number of ${ }^{125} \mathrm{I}-\alpha$-BGT binding sites, and these new sites are associated with functional receptors.

Electric lobe. Both the HSP and HSS prepared from the electric lobe increased the number of ACh receptors on the myotube surface (Fig. 1; Table II). The EL-HSP fraction, unlike the EO-HSP, did not bind ${ }^{125} \mathrm{I}-\alpha$-BGT (Table II) and thus contains no ACh receptors. These 
TABLE II

Properties of T. californica electric lobe extracts

Table II represents the values obtained from a single series of experiments using the same electric lobe extracts. The protein concentrations used were: EL-HSP, $6.6 \mathrm{mg} / \mathrm{ml}$ and EL-HSS, $4.6 \mathrm{mg} / \mathrm{ml}$. For ${ }^{125} \mathrm{I}-\alpha$-BGT binding to myotubes, ${ }^{125} \mathrm{I}-\alpha$-BGT binding was determined on day 8 of culture. The numbers are the means \pm SD for specific femtomoles of toxin bound per test condition. The numbers in parentheses are the ratios of values for a given test condition to the control value. For details of the ${ }^{125} \mathrm{I}-\alpha$-BGT binding to extracts and $\mathrm{ACh}$ sensitivity, see the legend to Table I.

\begin{tabular}{lccc}
\hline & Control & HSP & HSS \\
\hline${ }^{125} \mathrm{I}-\alpha$-BGT binding to & $4.4 \pm 0.5$ & $17.8 \pm 1.5$ & $12.6 \pm 1.5$ \\
myotubes & & $(4.0 \times)$ & $(2.9 \times)$ \\
${ }^{125}$ I- $\alpha$-BGT binding to & & 0.03 & \\
extracts & & & \\
ACh sensitivity & 108 & 470 & 381 \\
& & $(4.4 \times)$ & $(3.5 \times)$ \\
\hline
\end{tabular}

extracts produced increases in toxin binding of up to 2.9fold over control over a concentration range of 0.9 to 46 $\mu \mathrm{g}$ of protein added per day for the EL-HSS and up to 4.0 -fold over control over a concentration range of 1.3 to $66 \mu \mathrm{g}$ of protein added per day for the EL-HSP. Both of the EL fractions also produced significant increases $(p$ $<0.005$ ) in the ACh sensitivity of treated fibers (Table II). The sensitivity for untreated cells ranged between 10 and $710 \mathrm{mV} / \mathrm{nC}$ with a geometric mean of $108 \mathrm{mV} / \mathrm{nC}$ (118 sites on 25 myotubes). The sensitivity of EL-HSPtreated cells ranged between 100 and $1800 \mathrm{mV} / \mathrm{nC}$ with a geometric mean of $470 \mathrm{mV} / \mathrm{nC}$ (66 sites on 14 myotubes). For the EL-HSS, the range was 150 to $650 \mathrm{mV} /$ $\mathrm{nC}$ with a geometric mean of $381 \mathrm{mV} / \mathrm{nC}$ (26 sites on 7 myotubes).

The level of activity present in the electric lobe fractions was significantly higher than that found in the EOHSS. Attempts to concentrate the activity present in the EO-HSS (for example, by lyophilization) were not successful. For this reason, we did some preliminary biochemical characterization of the activity from the electric lobe, although our work was limited by the amount of material obtainable and the amount required for a subsequent bioassay.

EL-HSS fractions heated to $100^{\circ} \mathrm{C}$ (but not allowed to boil) for 5 min produced no significant increase in the amount of toxin bound to treated myotubes (1.04 times control values). Biological activity was not lost after treatment with trypsin (Worthington TRPCK grade) at a concentration of 0.1 or $1.0 \mathrm{mg} / \mathrm{ml}$ for $30 \mathrm{~min}$ at $37^{\circ} \mathrm{C}$. When the EL-HSS was fractionated on a column of BioGel P-150 (Fig. 2a), biological activity generally was confined to a broad peak consisting of fractions 9 to 11 ( $V_{e} / V_{0}$ of approximately 3 ). Higher molecular weight material in column fractions 4 to 6 caused a consistent decrease in the amount of ${ }^{125} \mathrm{I}-\alpha$-BGT bound. The same activity profile-the decrease in receptor number following exposure to leading fractions as well as the increase in receptor number following treatment with later fractions-was observed with three different preparations.

It is possible that the aclivity present in the EL-HSP is similar to that present in the HSS and that it pellets simply because it is contained in a membrane-bound compartment. To investigate this possibility, the EL-
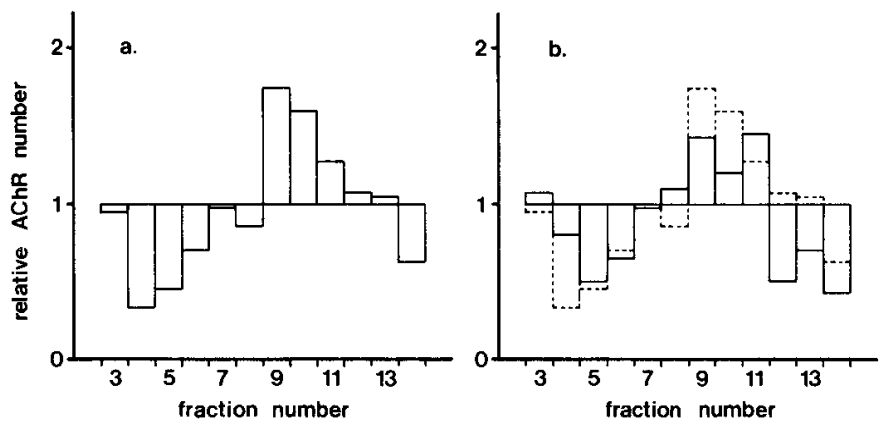

Figure 2. Elution profiles of $T$. californica electric lobe extracts on Bio-Gel P-150. One-milliter aliquots of EL-HSS and EL-HSP-R were applied to a $0.6 \times 15 \mathrm{~cm}$ column of Bio-Gel P150 (bed volume, $6.5 \mathrm{ml}$ ) and $0.75-\mathrm{ml}$ fractions were collected. The samples were applied in and the column eluted with Puck's saline without glucose, $\mathrm{pH} \mathrm{7.2.} \mathrm{Aliquots} \mathrm{of} \mathrm{each} \mathrm{fraction} \mathrm{were}$ added to microwell cultures for 4 days (see the legend to Fig. 1). In this experiment, $25 \mu \mathrm{l}$ were added per well to compensate for dilution during filtration. The ordinate represents the treated/control ratio of ${ }^{125} \mathrm{I}-\alpha$-BGT binding. $a$, Activity profile for EL-HSS; $b$, activity profiles for EL-HSS (dashed lines) and the material released from EL-HSP (solid lines). The column was calibrated with a mixture of dextran blue $\left(2 \times 10^{6}\right.$ daltons), cytochrome $c(12,400$ daltons), and phenol red (377 daltons); the peaks for each of these markers were fraction 3 , fraction 7 , and fraction 11, respectively.

HSP was subjected to conditions known to disrupt synaptic vesicles from Torpedo (Wagner and Kelley, 1979; J. Wagner, personal communication). Sonication, repeated cycles of freezing and thawing, and osmotic shock each released a small but significant (15 to $35 \%$ ) amount of the total activity present in the EL-HSP. Unfortunately, detergent solubilization of the fraction was not feasible since our activity appears associated with low molecular weight material and we could not remove the detergent by dialysis before subsequent bioassay. To compare this released activity with that present in the HSS, five electric lobes were homogenized and the resultant HSP fraction was resuspended in one-seventh the normal volume to concentrate the activity. The material was sonicated, subjected to two cycles of freezing and thawing, and then centrifuged to generate a supernatant or released fraction (EL-HSP-R). Like the EL-HSS, the activity present in the released material was found to be heat sensitive (more than $75 \%$ of the biological activity was lost after 5 min at $100^{\circ} \mathrm{C}$ ) but not sensitive to trypsin $(1.0 \mathrm{mg} / \mathrm{ml})$. Fractionation of EL-HSP-R on Bio-Gel P150 gave an activity profile similar to that obtained for the EL-HSS (Fig. $2 b$ ): biological activity was confined to fractions 9 to 11 , and fractions 4 to 6 produced a significant decrease in the amount of ${ }^{125} \mathrm{I}-\alpha-\mathrm{BGT}$ bound.

Electromotor nerves. Extracts prepared from the nerves that connect the electric lobe and organ (electromotor nerves) produced a significant increase in the total number of ACh receptors on chick myotubes (Fig. 1). The size of the increase was of the same order as that obtained with the electric lobe fractions. However, comparison of this activity with that from the electric lobe was difficult because the active substance in the nerves appears to be labile: activity often was lost within 1 to 2 weeks when stored under the same conditions as EL and 
EO extracts. In addition, electromotor extracts contain a substance that is apparently toxic to chick myotubes. After 2 or 3 days, treated cells appear vacuolated and begin to detach from the culture surface.

$A C h$ receptor clusters. Factors isolated from chick or mammalian tissues that cause an increase in the number of myotube ACh receptors (Podleski et al., 1978; Jessell et al., 1979) also cause an increase in the number of receptor clusters. We examined the effect of $T$. californica extracts on the number of receptor clusters by labeling myotubes with R-BGT.

Untreated cells had an average of 535 clusters $/ \mathrm{mm}^{2}$. Cells in sister cultures treated with EO-HSS for 4 days showed an increase in the number of clusters to 1180/ $\mathrm{mm}^{2}$, but cells treated with EO-LSP showed no increase in cluster number (Table III). Clusters also were identified in cultures treated with EL fractions. In this series of experiments, control myotubes had an average value of 440 clusters $/ \mathrm{mm}^{2}$, whereas cells treated with the ELHSP had a value of $1650 / \mathrm{mm}^{2}$ and those treated with EL-HSS a value of $1280 / \mathrm{mm}^{2}$ (Table III). An example of the $\mathrm{ACh}$ receptor distribution on control and EL-HSPtreated myotubes is seen in Figure 3.

To examine the effect of $T$. californica extracts on receptors that were already present in the myotube surface membrane, cells were treated with R-BGT, washed, and placed in fresh medium with or without EL or EO extracts. In one experiment in which extracts were present for $24 \mathrm{hr}$, untreated cells had an average of 42 clusters $/ \mathrm{mm}^{2}$. In contrast, values of 249 and $202 / \mathrm{mm}^{2}$ were obtained for EL-HSP- and EL-HSS-treated cells, respectively (Table III). The control value here differs by approximately 10 -fold from that for cells examined immediately after R-BGT labeling (above). This difference could be accounted for by receptor redistribution during the experiment; at least some of this difference may be accounted for by turnover, since the half-life of $\mathrm{ACh}$ receptors in chick myotubes grown at $37^{\circ} \mathrm{C}$ is about 1 day (Devreotes and Fambrough, 1975). In another experiment in which cells were exposed to extracts for

TABLE III

ACh receptor clusters on $T$. californica extract-treated chick myotubes

The values refer to the number of clusters per $\mathrm{mm}^{2}$ of myotube membrane. For clusters of all receptors, cells were treated for 4 days, from days 4 to 7 of culture, with the extract indicated, and on day 8 , RBGT was added for $60 \mathrm{~min}$; the cells were washed and fixed and the cluster number was determined. For clusters of prelabeled receptors, on day 7 of culture, myotubes were incubated with R-BGT for $60 \mathrm{~min}$, washed, and then placed in fresh medium with one of the extracts for 8 or $24 \mathrm{hr}$. Cells then were fixed and the cluster number was determined.

\begin{tabular}{lcrr}
\hline & $\begin{array}{c}\text { Clusters of } \\
\text { All Receptors }\end{array}$ & \multicolumn{2}{c}{$\begin{array}{c}\text { Clusters of Prelabeled } \\
\text { Receptors }\end{array}$} \\
\cline { 3 - 4 } & & $8 \mathrm{hr}$ & $24 \mathrm{hr}$ \\
\hline Control & 535 & 99 & \\
EO-LSP & 590 & 229 & \\
EO-HSS & 1180 & 321 & \\
& & & \\
Control & 440 & 89 & 42 \\
EL-HSP & 1650 & 232 & 249 \\
EL-HSS & 1280 & 245 & 202 \\
\hline
\end{tabular}
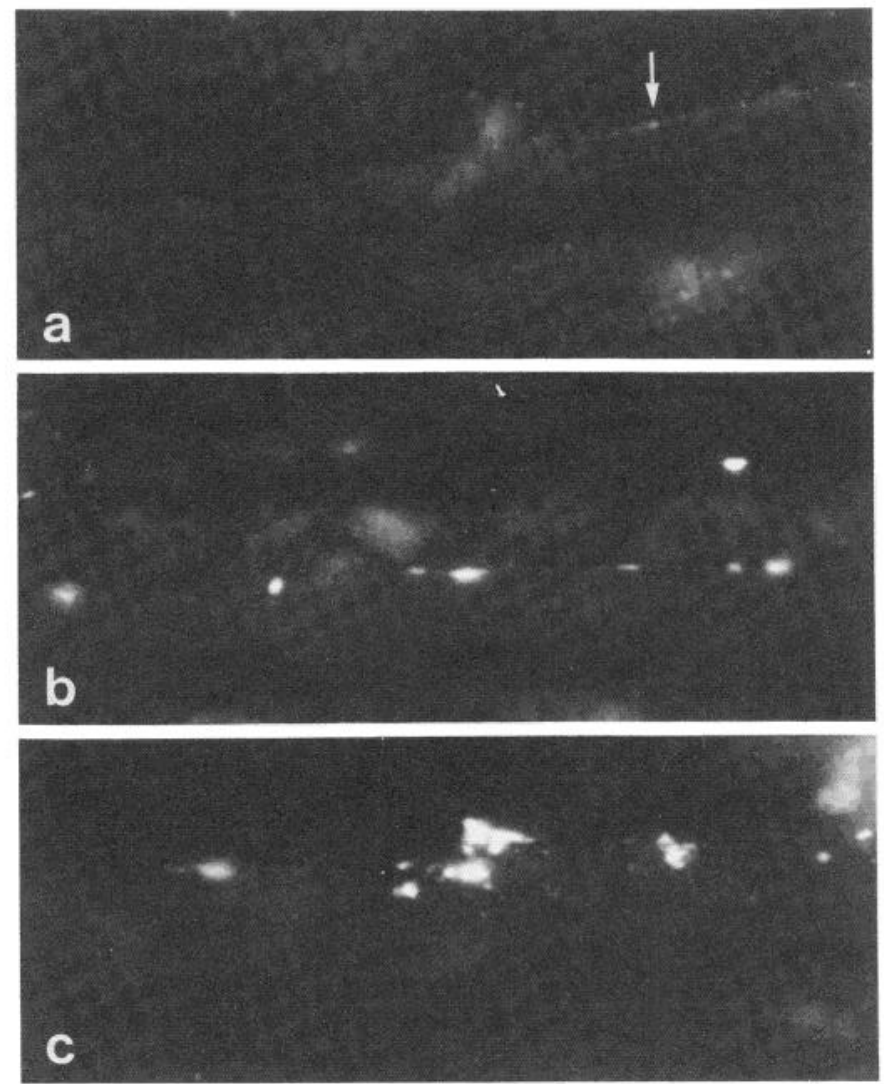

Figure 3. Distribution of $\mathrm{ACh}$ receptors on control and extract-treated chick myotubes. Cells grown on glass coverslips that were contained in $35-\mathrm{mm}$ dishes were fed daily with $1.5 \mathrm{ml}$ of $1 \%$ medium containing $100 \mu \mathrm{l}$ of saline $(a)$ or EL-HSP ( $b$ and $c)$. After 4 days, ACh receptors were labeled with R-BGT to reveal receptor clusters. Treated myotubes show a large increase in the number of receptor aggregates. Note that the size of receptor aggregates also is increased (see arrow in $a$ for comparison).

only $8 \mathrm{hr}$ after R-BGT labeling, control myotubes exhibited 89 clusters $/ \mathrm{mm}^{2}$ and cells treated with EL-HSP and EL-HSS exhibited 232 and 245 clusters $/ \mathrm{mm}^{2}$, respectively.

Similar results were obtained with EO-HSS and EOLSP (Table III). The EO-LSP effect is noteworthy because this fraction did not cause a significant increase in $\mathrm{ACh}$ receptor number or ACh sensitivity.

\section{Discussion}

We have shown that the electric lobe, the electromotor nerves, and the electric organs of Torpedo californica contain an activity that can increase the number of functional $\mathrm{ACh}$ receptors on uninnervated chick myotubes. This activity appears to be associated with a low molecular weight molecule since the peak of activity on Bio-Gel P-150 ran midway between the cytochrome $c$ peak (12,400 daltons) and that for phenol red (347 daltons). Jessell et al. (1979) showed that most of the activity present in chick brain extracts was found to be associated with low molecular weight acid/acetone-soluble material, although there was a significant amount of activity associated with material of higher molecular weight. We also have found a significant amount of receptor-inducing 
activity present in acid/acetone extracts of $T$. californica electric lobe and electric organ (not shown). Vyskocil and Syrovy (1979) found that the ability to induce $\mathrm{ACh}$ sensitivity in rat extensor digitorum longus muscle by extracts of rat sciatic nerve was associated exclusively with low molecular weight, dialyzable proteins. In contrast, Podleski et al. (1978) found that the ability to increase $\mathrm{ACh}$ receptor number in rat myotubes was associated with a higher molecular weight protein of about 100,000 daltons.

Given this apparent association with a low molecular weight species, it was interesting to note that activity was found in the electric lobe in both the HSP and HSS fractions. Activity could be released from the pellet fraction by treatments which disrupt membranes and the released material was similar to that in the EL-HSS on the basis of heat sensitivity, trypsin insensitivity, and filtration through Bio-Gel P-150. Although not strong criteria for identity, these results suggest that the same activity is present in both fractions. Since treatments which disrupt membrane-bound vesicles released activity from the EL-HSP, it is plausible that the material is contained in vesicles. It will be of interest to determine if vesicles that contain $\mathrm{ACh}$ also contain receptor-inducing activity.

On the basis of our results, the $T$. californica electromotor system does not appear to be an extremely rich source of this receptor-inducing activity. The EL-HSS fractions contain about twice as much receptor-inducing activity per $\mathrm{mg}$ of protein added than do similar fractions prepared from chick brain. However, the levels of activity present in the Torpedo electromotor system may well be difficult to ascertain since it appears that we also have an inhibitory activity present in these extracts. In gel filtration profiles, the early or higher molecular weight fractions contained material that did not appear to be toxic to or grossly affect the muscle cells but did cause a decrease in the number of $\mathrm{ACh}$ receptors on the myotube surface. Such an inhibitory aclivily may well mask the amount of stimulatory activity present in these extracts and purification of both the inhibitory and stimulatory activities will be required to clarify this point. The presence of such an inhibitory activity could account for the ambiguous results that we obtained with electromotor nerve extracts.

In addition to their effect on receptor number, watersoluble extracts from $T$. californica also increase the number of prelabeled receptor aggregates by a mechanism that is apparently independent of receptor synthesis. We do not know if the same molecules are responsible for both effects. Recently, Buc et al. in our laboratory (M. H. Buc, P. Nystrom, and G. D. Fischbach, manuscript in preparation) have found that highly purified fractions prepared by high pressure liquid chromatography from trifluoroacetic acid-soluble extracts of chick brain retain both of these activities: the ability to induce aggregation of prelabeled receptors as well as the ability to increase receptor number. In this case, both activities are associated with low molecular weight species.

Christian and co-workers (Christian et al., 1978; Bauer et al., 1981), however, found that a large protein of approximately 100,000 daltons would cause aggregation of $\mathrm{ACh}$ receptors on the myotube surface without increasing the total receptor number. Rubin et al. (1980) found that a particulate, basal lamina-containing fraction from $T$. californica electric organ would increase the clustering of prelabeled ACh receptors within 2 to $8 \mathrm{hr}$ after addition to myotubes. We found that the EO-LSP fraction, which presumably contains most of the basal lamina from the electric organ, will cause clustering of prelabeled receptors within $8 \mathrm{hr}$ without affecting the total receptor number or the number of receptor aggregates over 4 days. It is clear from our data, however, that the ability to induce receptor aggregation is not restricted to the basal lamina in T. californica since we have found such activity in both the EO-HSS and the EL-HSS fractions. It will be of interest to determine if this effect is caused by the same molecule that is responsible for stimulating $\mathrm{ACh}$ receptor synthesis.

In recent years, several different soluble "factors" have been described which affect the synthesis and/or clustering of myotube $\mathrm{ACh}$ receptors (Podleski et al., 1978; Christian et al., 1978; Jessell et al., 1979). Recently, Peng et al. (1981) reported that $\mathrm{ACh}$ receptor clusters would form at contact sites between muscle cells and positively charged latex beads. The fact that high pressure liquid chromatography studies in this laboratory have shown that the activity is associated with only a few specific fractions would tend to rule out the theory that these observations represent a nonspecific or ionic effect rather than a true biological one. However, the relationship between this activity from chick brain and those from other sources, including Torpedo, must be established. It remains to be demonstrated that molecules capable of inducing the synthesis and/or aggregation of ACh receptors are released from nerve terminals at forming or mature synapses. However, the fact that receptor-inducing activity from Torpedo electromotor tissue is active on chick myotubes suggests that molecules with such an activity may indeed play a key role in the formation of cholinergic synapses.

Cohen and Weldon (1980) demonstrated that spinal cord cells, many of which are cholinergic (Anderson et al., 1977, 1979) would affect the distribution of $\mathrm{ACh}$ receptors on Xenopus myotomal muscle but that presumably non-cholinergic dorsal root ganglion or sympathetic ganglion cells would not. Medium conditioned by chick ciliary ganglion cells, a pure population of cholinergic cells, but not by dorsal root ganglion cells, was found to cause increased synthesis of $\mathrm{ACh}$ receptors on chick myotubes (Jessell et al., 1979; Fischbach and Jessell, 1980). The results that we have described for the Torpedo electromotor system lend further weight to the idea that $\mathrm{ACh}$ receptor-inducing activity is present in cholinergic neurons since only cholinergic neurons are known to be present in the Torpedo electric lobe and organ (Feldberg and Fessard, 1942; Able-Fessard and Buser, 1954; Tsuji, 1977). Taken together, these results are suggestive of a motor neuron-specific molecule which functions in some capacity during the formation, or in the maintenance, of the neuromuscular junction, but it has not yet been shown unambiguously that such an activity is unique to cholinergic cells and absent from non-cholinergic cell populations. 


\section{References}

Able-Fessard, D., and P. Buser (1954) Analyse microphysiologique de la transmission reflexe au niveau du lobe electrique de la Torpille (Torpedo marmorata). J. Physiol. (Paris) 46: 923-946.

Anderson, M. J., M. W. Cohen, and E. Zorychta (1977) Effects of innervation on the distribution of acetylcholine receptors on cultured muscle cells. J. Physiol. (Lond.) 268: 731-756.

Anderson, M. J., Y. Kidokoro, and R. Greuner (1979) Correlation between acetylcholine receptor localization and spontaneous synaptic potentials in cultures of nerve and muscle. Brain Res. 166: 185-190.

Bauer, H. C., M. P. Daniels, P. A. Pudimat, L. Jacques, H. Sugiyama, and C. N. Christian (1981) Characterization and partial purification of a neuronal factor which increases acetylcholine receptor aggregation on cultured muscle cells. Brain Res. 209: 395-404.

Bennett, M. V. L. (1970) Comparative physiology: Electric organs. Annu. Rev. Physiol. 32: 471-528.

Christian, C. N., M. P. Daniels, H. Sugiyama, Z. Vogel, L. Jacques, and P. G. Nelson (1978) A factor from neurons increases the number of acetylcholine receptor aggregates on cultured muscle cells. Proc. Natl. Acad. Sci. U. S. A. 75: 40114015.

Cohen, M. W., and P. R. Weldon (1980) Localization of acetylcholine receptors and synaptic ultrastructure at nerve-muscle contacts in culture: Dependence on nerve type. J. Cell Biol. 86: $388-401$.

Devreotes, P. N., and D. M. Fambrough (1975) Acetylcholine receptor turnover in membranes of developing muscle fibers. J. Cell Biol. 65: 335-358.

Feldberg, W., and A. Fessard (1942) The cholinergic nature of the nerves to the electric organ of the torpedo (Torpedo marmorata). J. Physiol. (Lond.) 101: 200-216.

Fischbach, G. D. (1972) Synapse formation between dissociated nerve and muscle cells in low density cell cultures. Dev. Biol. 28: 407-429.

Fischbach, G. D., and T. M. Jessell (1980) Induction of ACh receptors and receptor clusters in embryonic myotubes. INSERM Symp. 13: 301-311.

Jessell, T. M., R. E. Siegel, and G. D. Fischbach (1979) Induc- tion of acetylcholine receptors on cultured skeletal muscle by a factor extracted from brain and spinal cord. Proc. Natl. Acad. Sci. U. S. A. 76: 5397-5401.

Peng, H. B., P. -C. Cheng, and P. W. Luther (1981) Formation of $\mathrm{ACh}$ receptor clusters induced by positively charged latex beads. Nature 292: 831-834.

Podleski, T. R., D. Axelrod, P. Ravdin, I. Greenberg, M. M. Johnson, and M. M. Saltpeter (1978) Nerve extract induces increase and redistribution of acetylcholine receptors on cloned muscle cells. Proc. Natl. Acad. Sci. U. S. A. 75: 20352039.

Prives, J., C. Christian, S. Penman, and K. Olden (1980) Neuronal regulation of muscle acetylcholine receptors: Role of muscle cytoskeleton and receptor carbohydrate. In Tissue Culture in Neurobiology, E. Giacobini, A. Vernadakis, and A. Shahar, eds., pp. 35-52, Raven Press, New York.

Puck, '1. 'I., S. J. Cieciura, and A. Robinson (1958) Genetics of somatic mammalian cells. III. Long-term cultivation of euploid cells from human and animal subjects. J. Exp. Med. 108: 945-956.

Ravdin, P., and D. Axelrod (1977) Fluorescent tetramethyl rhodamine derivatives of $\alpha$-bungarotoxin: Preparation, separation, and characterization. Anal. Biochem. 80: 585-592.

Rubin, L. L., A. S. Gordon, and U. J. McMahan (1980) Basal lamina fraction from the electric organ of Torpedo organizes acetylcholine receptors on cultured myotubes. Soc. Neurosci. Abstr. 6: 330 .

Sobel, A., M. Weber, and J. -P. Changeux (1977) Large-scale purification of the acetylcholine-receptor protein in its membrane-bound and detergent-extracted forms from Torpedo marmorata electric organ. Eur. J. Biochem. 80: 214-224.

Tsuji, S. (1977) AChE positive electromotoneurons in the electric lobe of Torpedo marmorata. Brain Res. 124: 352-356.

Vyskocil, F., and I. Syrovy (1979) Do peripheral nerves contain a factor inducing acetylcholine sensitivity in skeletal muscle. Experientia 35: 218-219.

Wagner, J. A., and R. B. Kelley (1979) Topological organization of proteins in an intracellular secretory organelle: The synaptic vesicle. Proc. Natl. Acad. Sci. U. S. A. 76: 4126-4130.

Whittaker, V. P. (1977) The electromotor system of Torpedo. A model cholinergic system. Naturwissenschaften 64: 606611. 